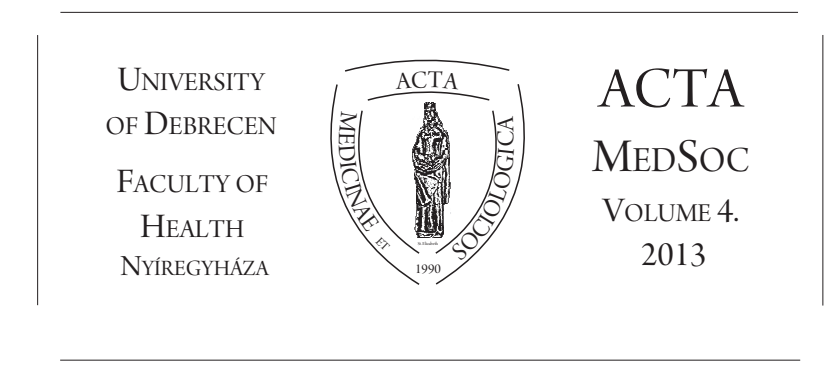

\title{
Személyes szolgáltatások nyújtása a szlovák szociális intézményekben
}

\author{
Keketiová, Mačkinová, Mareková, Vaverčáková
}

Trnavská Univerzita v Trnave, Szlovákia

DOI: $10.19055 / \mathrm{ams} .2013 .4 / 8-9 / 11$

Fontos felhívni a szolgáltatást nyújtók figyelmét a szociális munka menedzsmentjének jelentôségére és gyakorlatba való átültetésére, a szociális szolgáltatásokat nyújtók részérôl. A szervezeti egység irányításának minden fokán a menedzser célja az intézmény versenyképességének elérése, a nyújtott szolgáltatások minőségének minduntalan javítása a rendelkezésre álló emberi potenciál maximális kihasználása mellett. A szociális politika a gyakorlatban intézményi eszközökkel rendelkezik, melyek segítségével a szociális munka célzott ügyfélcsoportok segítésére irányul miközben ilyen eszközök a közigazgatás szervei és egyúttal a szociális szolgáltatások egyes intézményei is. A létrehozott múködőképes és hatékony menedzsment az irányítás minden szintjén képes megfelelni gyakorlati kihívásoknak, valamint teljesíti azokat a feladatokat, melyek a vonatkozó jogszabályokból, a szervezet céljaiból és terveiból következnek, melyek végül az ügyfél mindennapi életének minôségét és a szociális szakember munkájának fontosságát és értelmét jelentik a szociális munka módszereinek segítségével.

A menedzsment a szociális munkában olyan ismeretek összességét jelenti, melyet minden vezetô dolgozónak elméleti szinten ismernie és a gyakorlatban alkalmaznia kellene a szociális intézményben végzett menedzseri munkája során. A múltban alkalmazott menedzseri praktikák és azok új trendbe, gyakorlatba és alkalmazásokba való transzformálása a szociális munkában a szociális munka menedzsmentje keletkezésének és fejlődésének ok-okozati összefüggéseire kell, hogy rámutasson. A menedzserek hatékony, gyakorlati módszerei és helyes döntései az eljárások és 
módszerek elfogadása során pozitívan tükröződnek vissza az ügyfeleknek nyújtott szolgáltatásokban, valamint a társadalom szociális hiányosságaiba való beavatkozás, valamint a problémák megelôzése során.

A menedzsment a szociális munkában olyan terület, mely feltétlen figyelmet követel, mivel a szociális munka tevékenységei gyakran a konkrét szociális munkás menedzser-képességeitól függnek az ügyféllel való munkája során (casework) a szociális munkás mint az ügyfél szociális problémáinak megoldásában gyakran együttmúködő szakemberek csapatának koordinátora szerepében is (case management), továbbá a szociális munkás mint az azonos szakmájú de eltérô szociális munkások csoportvezetője szerepkörében (service, team management) és végül a vezetôpozícióban lévô - bizonyos szociális szubjektum irányítását ellátó dolgozó - szociális munkás szerepében is (intstitution management). A szociális intézmények összetétele fenntartójuktól függốen nagyon különbözô. Az intézményekben a szociális munka jellege, tartalma és minősége gyakran abból a tényból indul ki, hogy a fenntartó az önkormányzat, a harmadik szektor vagy a szubjektum magánjogi jelleggel bír. Nem utolsó sorban olyan szubjektumok is léteznek, melyek az államigazgatásban tevékenykednek, tehát az államigazgatási intézmények szervezeti szerkezetében találhatók, a szociális munka szempontjából főképp a munka-, szociális és családügyi hivatalokról van szó. Ez a meglehetôsen szerteágazó struktúra megkülönböztetett hozzáállást követel meg a menedzsment lehetôségei és szükségletei tekintetében.

\section{Az élet minôsége (Quality of life) a szociális szolgáltatások intézményeiben}

A múlt század második felétől az élet minősége fogalmát különbözô tudományágak kezdték felfedezni és vizsgálgatni. Az élet minósége összetett és nagyon széles fogalom. Az emberi létezés, az élet értelme és maga a létezés megértését érinti.

Az élet minősége az emberi és társadalmi fejlődést érintő szociális, egészségügyi, gazdasági és környezeti feltételek kölcsönhatásának eredménye. Egyrészt a jó élethez szükséges objektív feltételeket, másrészt a jó élet szubjektív megélését jelenti. A szociális és kulturális szükségletek kielégítése az anyagi bôségtôl függóen, az egyén társadalmi elfogadása és a fizikai egészség alkotják az élet minôségének objektív oldalát. A szubjektív minőség a jó életérzésrôl, kényelemrool és a dolgainkkal való megelégedettségről szól. Méréséhez ún. „puha adatokat” használnak - melyeket közvélemény-kutatások során szereznek meg (www.rozvojovevzdelavanie.sk, 2011).

Az élet minôségének összetevôi időben változók. A szubjektív kényelem, mely erôsen függ az aktuális érzelmi állapottól, gyorsan változhat. A szociális szerepekben való múködés szintén gyorsan romolhat, többnyire ez eltart bizonyos ideig. Džuka (2004) megkülönbözteti az élet szubjektív minôségét - a személy értékelt életkörülményei individuális elbírálása alapján és a szubjektív kényelmet - emocionális 
rendszerben értékelt saját élet feltételei. Az élet minôsége multidimenzionális fogalomként Ondrejko, Drimalová és Frankl (2000) szerint öt alapterületból áll, melyet szubjektív és objektív paraméterek jellemeznek:

1. pszichikai állapot,

2. fizikai állapot,

3. funkcionális állapot, mely lehetóvé teszi a fizikai és pszichikai terheléshez való alkalmazkodást,

4. a szociális viszonyok területe, mely a személy kommunikációs képességével és a szélesebb társadalmi életbe való betagolódásával határozható meg,

5. gazdasági - pénzügyi terület.

Az élet minősége, mint szubjektív kényelemérzés is definiálható, mely az élet - adott személy számára fontos - területeivel való elégedettségéból vagy elégedetlenségéből fakad.

A szervezet számára fontos az új módszerek használata az emberi eróforrások menedzselésében. Bevezetésük a menedzsment számára nagy kihívás, mert ezeket a módszereket már a konkrét munkafolyamatban kell bevezetni és folyamatosan korrigálni a konkrét szükségletek szerint. Ezek a módszerek pozitív hatással vannak nem csak a munkavállalókra, hanem elsôsorban, javítja az ügyfelek életminóségét. Az új módszerek bevezetése a szociális szolgáltatások terén nem csak növeli a szociális szolgáltatások minőségét, hanem egyúttal a munka minôségének javulásának a tényleges kedvezményezettje a szociális szolgáltatások kapója. Az új módszerek bevezetésénél a menedzsment új kihívásokkal találta szemben magát. Többek között az anyagi fedezet, technikai segédeszközök hiányával a nem megfelelő helységek hiányával. Nem utolsósorban nem volt biztosítva a kellóképpen képzett személyzet sem. Az érvényben lévô NR SR 448/2008 törvény értelmében a szolgáltatások amelyek az életminőség javítását szolgálják térítésmentést élveznek, tehát a kliens számára ingyenesek . Például a szükséges Snozelen helységek kialakításához többségében a szolgáltatóknak az aktuális évben nincs meg a szükséges anyagi fedezet. Ezért a menedzsmentnek kell megkeresni azokat a különféle grandokat, adakozókat akik elôsegítik a személyes szolgáltatást nyújtó intézetek lakóinak életminőség javítását.

\section{Jó gyakorlatok: a „KAMILKA” Szociális Szolgáltatások In- tézménye bemutatása}

A Szociális Szolgáltatások Lakóotthona (SzSzL) gyermekeknek és felnôtteknek hetes és egész éves bentlakással Mánya településen 1975. április 18-án létesült, mint a Mentálisan sérült gyermekek és fiatalok szociális gondozóotthona. Fenntartója az 
érsekújvári (Nové Zámky) Járási Nemzeti Bizottság volt. 1996. augusztus 26-án a mányai Mentálisan sérült gyermekek és fiatalok szociális gondozóotthona a Nyitrai (Nitra) Kerületi Hivatal fennhatósága alá került. 1998. július 1-tól az intézmény megnevezése Szociális Szolgáltatások Lakóotthona gyermekeknek és felnôtteknek Mánya. A közigazgatási reform következményeként az intézmény fenntartója 2004. január 1-tól a Nyitra Megyei Önkormányzat, a megnevezése pedig Szociális Szolgáltatások Lakóotthona (SzSzL) gyermekeknek és felnőtteknek hetes és egész éves bentlakással Mánya lett. 2009. június 1-én a Nyitra Megyei Önkormányzat az alapító okirathoz függeléket adott ki, mely szerint a megnevezés „KAMILKA” Szociális Szolgáltatások Intézménye Mánya lett.

Az intézmény a késő barokk kastély egyszintes épületében székel, melyet a 18ik század második felében a helyi földesurak, Malonayék és Kollerék építtettek. A kastély utolsó tulajdonosa Földváry Géza gróf volt, aki a második világháború után Magyarországra költözött, ott is hunyt el. Az USA-ban, Kaliforniában élő leszármazottai az intézményt többször is meglátogatták. Maximális megelégedésüket fejezték ki annak tekintetében, hogy az épület szociális célokra és mentálisan sérült személyek gondozására szolgál.

A kastély részét képezi a közeli kb. 10 hektáros erdőpark is, melyben több védett fafajta is megtalálható (platánok, mamutfenyôk, stb.). Napjainkban sport-, rekreációs és kulturális célokra használják. Fóképp a nyári hónapokban munkatevékenységre is használják.

A kastély épületének beosztása csak részben megfelelő. A földszinti részben találhatók a múszaki üzemrészek: konyha, étterem, mosoda, ruhaszárító, raktárhelyiségek, adminisztratív helyiségek, mozgás céljaira szolgáló helyiség. A kastély emeletén találhatók a hálóhelyiségek, játékszobák, fürdôszoba, WC, társalgó, multiszenzorikus helyiség. Az intézményben fokozatosan oldják meg az akadálymentesítést. Az immobilis és részben mobilis ügyfelek szállítására lépcsólifteket létesítettek.

\section{A SzSzI-ben nyújtott szolgáltatások fajtája és formája}

A „KAMILKA” Szociális Szolgáltatások Intézménye Mánya (továbbiakban SzSzI) bentlakásos szociális szolgáltatást nyújt a szociális szolgáltatások lakóotthonában, támogatott lakhatási intézményben és specializált intézményben. A szociális szolgáltatást hetes és egész éves formában nyújtják.

A „KAMILKA” SzSzI Mánya a Nyitra Megyei Önkormányzat által kiadott alapító okirat értelmében értelmi fogyatékkal élô gyermekek és felnôttek számára nyújt teljes körû gondozást.

Koedukált intézményrôl van szó, mely jelenleg az ügyfelek három éves korától egész természetes halálukig bezárólag nyújt szociális szolgáltatást. Az intézményben 95 nô és 4 férfi van elhelyezve, koruk 7-től 56 évig terjed. A mozgásképesség szempontjából a szolgáltatatást használók csoportjai: mozgásképes 53, részben mozgásképes 
17, súlyosan mozgássérült 8 és mozgásképtelen 21.

Az ügyfelek összetétele a speciális diagnózisok szempontjából a következő: (1. táblázat)

\begin{tabular}{|c|c|c|}
\hline Mentálisan akadályozott & könnyű fokozat & 0 ügyfél \\
\hline & közepes fokozat & 44 ügyfél \\
\hline & súlyos fokozat & 53 ügyfél \\
\hline
\end{tabular}

\begin{tabular}{|c|c|}
\hline Agyi eredetű gyermekbénulás & 18 \\
\hline Epilepszia & 22 \\
\hline Skizofrénia & 3 \\
\hline Down szindróma & 12 \\
\hline Szív- és érrendszeri megbetegedések & 10 \\
\hline Mozgásszervi megbetegedések & 25 \\
\hline Diabetes mellitus & 3 \\
\hline Amaurosis & 6 \\
\hline Surdomutitas & 3 \\
\hline Inkontinencia & 39 \\
\hline
\end{tabular}

1. táblázat: Ügyfelek összetétele speciális diagnózisok szempontjából.

A Szociális Szolgáltatások Intézményében az ügyfeleknek szakmai, gondozási és egyéb tevékenységeket nyújtanak a szociális szolgáltatásokról szóló 448/2008 számú törvény értelmében, az egyes típusú szociális szolgáltatásokra meghatározott mértékben.

A gyógyító-megelôző gondozást nem állami létesítésû egészségügyi szolgáltatók biztosítják. Az ápolói gondoskodást egészségügyi személyzet biztosítja három múszakban (specializálódott és egészségügyi nôvérek, szakképzett ápolók, ápolók és gondozók).

A szociális rehabilitáció keretén belül végzett nevelési tevékenység alapvetô célja az ügyfelekkel történő olyan tevékenységek begyakorlása, melyek az önállóságot, függetlenséget, önellátást támogatják. Kiemelt cél az önkiszolgáláshoz, háztartásvezetéshez és az alapvetô szociális tevékenységekhez szükséges képességek aktiválása és a megszokások megerôsítése. Nagy figyelmet fordítunk az önbizalom, a hasznosság érzésének megerôsítésére és az ügyfelek teljes szocializálódására és közösségi integrációjára. Az önbizalom növeléséhez fóleg az ügyfeleink nyilvános fellépése járul hozzá, ezeket az eseményeket a helyi községi hivatal szervezi és a község lakosai is részt vesznek rajta. 
A munkatevékenység során az ügyfelek az intézmény területének gondozásában, a kert termelési munkálataiban, mosodai segédmunkákban veszik ki részüket. Az ergoterápia során különböző termékeket készítenek, melyeket a kézimunka kiállításon mutatnak be.

A rekreációs tevékenység fóképp a tavaszi és nyári hónapokban valósul meg. A közeli bellegszencsei (Podhájska) termálfürdő meglátogatása a meleg nyári napok legkedveltebb tevékenységei közé tartozik. Rekreációs-relaxációs üdülésekre a Hédelben (Hiadež) található nyaralót is használják.

Az intézmény és a szomszédos szociális szolgáltatások intézményei ügyfelei részére rendezett hagyományos rendezvények közé tartoznak a farsangi, húsvéti, Katalinnapi és Mikulás-napi mulatságok.

Az erdôpark területe kedvezô időjárás esetén szalonnasütés, valamint különbözô sportesemények céljaira szolgál. Az intézmény ügyfeleivel számos szabadidôs és sport rendezvényen részt vesznek (pl. nemzetközi sportjátékok Tloskovban, színjátszók megyei seregszemléje, stb.).

\section{Új módszerek a szociális szolgáltatások intézményében}

A KAMILKA Szociális Szolgáltatások Intézménye Mánya célja az ügyfeleknek nyújtott szabadidős tevékenységek kínálatának bơvítése, melynek fố célja az életminôség javítása. Minden egyes ügyfélnél egyedi fejlesztési terv alapján foglalkozunk, melyben tiszteletben tartjuk az ügyfél biológiai, pszichikai, szociális és lelki szükségleteit.

A tapasztalatok azt mutatják, hogy a mentális fogyatékkal élő emberek is bizonyos módon állandóan fejleszthetők. Tekintettel arra az általánosan elfogadott véleményre, hogy minden egyes, a legkisebb fejlődés is az életük minôségének javítását jelenti, a munka jelentősége éppen az olyan új lehetôségek és előfeltételek kialakításában rejlik, melyek elősegítik folyamatos fejlődésüket, önkifejezésüket, jogaik érvényesítését, ami önállósodásukhoz, önmegvalósításukhoz és a független élethez vezet.

Matulay írja, hogy „az agy fejlődésére és a neuronok közti kapcsolatok kialakítására óriási hatással van a különbözô ingerek gyakorisága és intenzitása. Egyetlen inger, pl. egy izom mozgása, lehetôvé teszi az impulzusok kibővítését és ezzel több ezer neuron növekedését. A motorikus fejlesztés a teljes kezelésen belül a további tanulás pótolhatatlan előfeltétele, mégpedig a személyiség valamennyi összetevôjében". (Matulay, 1986:36)

Švarcová szerint: „A fogyatékkal élók világa talán más, de beléphetünk oda, ha képesek vagyunk megtalálni a megfelelő ajtót." (Švarcová, 2003:110) 
A szociális szolgáltatások intézményében a megfelelő területi feltétel megteremtését követôen igyekeznek minél több új módszert bevezetni a gyakorlatba. Szponzori támogatás segítségével sikerült a dolgozókat a bazális stimuláció területén kiképezni, és létrehozni a snoezelen multifunkciós helyiséget. Az új módszerek célja nem csupán az ember érzékszerveit stimulálni és hatni rájuk különböző stimulálók segítségével, és így stimulálni a személyt fizikai és mentális tevékenységre, hanem negatív megnyilvánulások esetén az ügyfelet nyugalmi vagy relaxációs állapotba is juttatni.

A szociális szolgáltatásokról szóló 448/2008 sz. törvény értelmében, amennyiben a szociális szolgáltatások nyújtója rendelkezik ahhoz szükséges körülményekkel, a nyújtott szociális szolgáltatások minôségének javítása céljából zeneterápiát, múvészetterápiát, hippoterápiát, canisterápiát, biblioterápiát, hidroterápiát, aromaterápiát és tevékenységterápiát nyújthat.

Napjainkban nagy figyelmet szentelnek a mentálisan sérült emberek gondozása keretén belül a nem hagyományos módszerek fejlesztésének. Az említett módszerek a testi és mentális fogyatékkal élő emberek lehetôségeiből, képességeiből és érdeklődési körükból indulnak ki, ill. tartják ezeket tiszteletben.

Az állatasszisztált terápia fogalma alatt az állat emberre gyakorolt pozitív, valamint gyógyító hatását értjük. Az állat az ügyfél számára sok mindent jelenthet - kommunikáció létesítése a környezô világgal, felvidámítás a szomorú pillanatokban, fizikai fájdalmak esetén is segíthet, vagy megtornáztatja a merev izmokat. Amennyiben a memória, motorika, kommunikáció javítását vagy a stressz enyhítését célozzuk meg, az állat mindig a köztes résztvevô, az ún. kooterapeuta szerepét tölti be. Az állatterápia az ember és állat kölcsönös pozitív hatásának kihasználásában rejlik (Mojžišová, 2000).

A hippoterápia (lóval való gyógyítás) egy olyan rehabilitációs módszer, mely a ló emberre való komplex hatását kihasználja. Az állatterápia legelterjedtebb formája. Az ember - állat viszonyában az utóbbi években a ló különleges helyet foglal el.

A canisterápia segéd rehabilitációs gyógykezelési módszer, melyet többféle fogyatéknál különböző klinikai (pszichopatológiai, pszichiátriai és geriátriai) állapotok esetén alkalmaznak, melynél az állat - kutya pozitív hatását az ember testi, lelki és szociális egészségének támogatására használják ki (WHO). Megnevezése a latin Canis - kutya és terápia a görög Therapeia - ápolás, gyógyítás szavakból származik. A canisterápia az állatterápia számos formája közül az egyik bevált módszer (Vojtěchovský, 1999).

A szocioterápia a társasággal való gyógyítás, pl. problémás viselkedés és viszonyok esetén, de a félelmet keltô zaklatás és agresszivitás megelôzése esetén is. Agyi eredetû gyermekbénulásos gyermekek, drogfüggó, hiperaktív vagy ellenkezóleg au- 
tista gyermekek, vaksággal, süketséggel, beszédzavarral és ezek kombinációjával sújtott emberek részére alkalmas.

Pszichoterápia alatt pszichológiai eszközökkel való gyógyítást értünk. Mindazokban az esetekben érvényesül, ahol az egészségügyi panaszokat pszichikai hatások okozzák, pl. kínzott gyermek szindróma, könnyư agyi diszfunkciók, Alzheimer-kór, agyi eredetú gyermekbénulás, stb.

A fizioterápia alatt meleggel (animális átmelegítés) való gyógyítás értendô egyes mozgásszervi és idegrendszeri megbetegedéseknél, pl. agyi eredetú gyermekbénulás, epilepszia, demencia, stb.

A felinoterápia az ember és macska közötti pozitív interakciót használja ki, nem csupán az egészség támogatásában, hanem a gyógyításhoz is. Szomatikus és fơleg pszichikai panaszok és terhelések kezelésének kiegészítő formájáról van szó, a macskával való személyes kapcsolat segítségével. A kutya és ló mellett a macska az ember leggyakrabban nevelt társa. A felinoterápiát a világban a szomatikus, pszichikai panaszok és személyiségzavarok kiegészítő gyógykezeléseként ismerik.

A delfinterápia nálunk nem szokványos és csaknem ismeretlen állatterápia, mely kedvezően hat az ügyfélre a delfin természetes környezetében. Egy olyan élményformáról van szó, mely a mozgástevékenységgel együtt kedvezóen hat a pszichikára. A delfinekrôl úgy tartják, hogy képesek az emberrel különös bioenergikus kapcsolatot létesíteni. A több éves kutatások a gyógyászatban és más ágazatoknál érvényesültek, ahol a delfinek terápiában betöltött szerepe nem helyettesíthetô. Habár a delfinek a nagytestú állatok közé tartoznak, ennek ellenére hozzáállásukkal nagyon gyorsan megszüntetik a velük való érintkezésból adódó félelmeket.

Az ornitoterápia nem túl elterjedt terápiás diszciplína. A legnagyobb számú pozitív eredményt idôsebb személyeknél értek el. A papagájok ideális partnerek az ember lelki egyensúlyának javításánál és a negatív érzelmi folyamatok enyhítésénél.

A snoozelen nálunk meglehetôsen új módszer, terápiás, relaxációs és szabadidôs felhasználással. A snoozelen terápiát speciálisan kialakított környezetben, kellemes légkörben alkalmazzák. A relaxálásra, valamint az egyes érzékek stimulálására fókuszál.

Az egyes érzékek stimulálásához a következőket használják: fényeffektusok (optikai stimuláció), hangeffektusok (auditív stimuláció), illatok (olfaktorikus stimuláció), tárgyak és anyagok (taktilis - haptikus stimuláció), vesztibuláris stimuláció segédeszközei, vibrációs stimuláció eszközei.

A bazális stimuláció abból indul ki, hogy minden ember minden helyzetben képes valamely érzékszervével valamit érzékelni. Mindig képes megnyílni a világ felé és 
kommunikálni környezetével. Egyesek csupán gesztusokkal, fejmozdulattal, a légzés frekvenciájának változásával, az izzadság szekréciójának változásával, pislantással, stb. kommunikálnak. (Friedlová, 2002).

A zeneterápia élményterápia, mely során az ügyfél más módszerekkel kommunikálhat, mint az megszokott. A zeneterápia elsôsorban érzéki síkon kezdődik, fôleg az auditív csatornában dolgozik, de az egyéb érzékeket sem kerüli el. Az érzékszervi érzékelésekhez és reakciókhoz emóciók kötődnek (Zeleiová, 2007). A melódia, ritmus és kellemes képzetek előhívásának hatásáról van szó. A ritmikai nevelés fontos az elmaradó motorikus fejlődés és szociális fejlődés esetén.

A tánc az egyszerú mozgások letükrözése, és az arc mimikai kifejezéseinek keretén belül is terápiásan hat, oly módon, hogy megerôsíti az emberben a bizonyosság és biztonság érzését, mivel olyan személy van mellette, akivel egy kommunikációs szinten van (Fux, 1991). A testmozgás alkotó tevékenység széleskörú stimuláló és fejlesztő funkcióval a sérült szervek és rendszerek terén. A teljes pszichomotorikus kondíció megszerzésének eszköze a pszichoszomatikus állapotok szabályozásával. Ezek a mozgástevékenységek a legkedveltebbek ügyfeleink körében és a napirendben állandó helyet foglalnak el.

Az aromaterápia több szinten hat a lélek és a test harmóniájának megújítására, mely az optimális egészséghez és jó vitalitáshoz szükséges. Az emberek több mint 6000 éve ismerik a természetes növényi olajok hatásait, értékelik ezek gyógyító, tisztító, védő és erôsítő tulajdonságait. Az aromaterápia különféle illatokat használ a szervezet állapotának javítására, a szervezet támogatására és relaxálásra. Inhalálás és fürdôk formájában alkalmazzák.

Az arteterápia pszichoterapeutikus diszciplína, mely gyógyítási célokra a múvészeti formáknak megfelelő formákat és eszközöket használja. Az elsôdleges cél nem mûalkotás létrehozása, hanem az alkotóképesség fejlesztésével és a személy számára fontos téma feldolgozásával az ember nehézségeinek eltávolítása vagy enyhítése.

A biblioterápia a könyv ügyfélre kifejtett hatását használja ki. Introvert (zárkózott) és racionális beállítottságú ügyfelek esetében használják. A terápia nem csak az irodalmi múveket, hanem az ügyfél saját alkotásait is felhasználja. Feltételezik, hogy az irodalomban az emberiség valamennyi gondja tükröződött a különbözô életkorokban. Az ügyfél nézeteit nem csupán az irodalmi mú hôseivel konfrontálhatja, hanem közös olvasásnál a csoport többi tagjának nézeteivel is.

A drámaterápia terápiás - nevelési módszer, mely a színjátszás különböző formáit használja fel (jelenetek, történetek, szerepek, etüdök) az emocionálisan és szociálisan sérült gyermekek és felnôttek pozitív stimulációjára, viselkedésük, megéléseik és álláspontjaik korrekciójára. A drámajátékok fejlesztik az aktivitást és 
alkotókészséget, javítják a szociális szokásokat és a kommunikációs képességet. A drámajátékok a szociális tanulás és fejlődés számos lehetôségét biztosítják (Horňáková, 1999).

A Szlovák Köztársaságban szociális szolgáltatásokat nyújthatnak állami és magán szervezetek egyaránt. Az állami szolgáltatók költségvetését az autonóm régió (VUC), város, falu saját költségvetéséból biztosítja. A nem állami szolgáltató költségvetését az állam biztosítja csak abban az esetben ha az autonóm régió elöfizet erre a szolgáltatásra. Tehát a magán szolgáltató függ a különbözö anyagi forrásokból származó támogatástól. A költség térítésben is különbségek vannak. A magánszolgáltatónak a kliens a költségek 50\% téríti. Az állami szolgáltatónál a költség térítésének százalékát az „Általánosan Kötelezö Rendelkezés(VZN)” szabja meg, s ez helyenként eltéró is lehet.

Az előző 195/1998 a szociális segítségrôl szóló törvényt felváltotta a módosított 44/2008 törvény melyben változások lettek a szolgáltatást nyújtó intézmények anyagi finanszírozását illetően.

Bevezetésre kerültek a „standardok” (kötelező alapszolgáltatás) és a kompetencia átruházása magára a községre ahol a gondozottnak állandó bejelentett lakhelye van. Jelenleg a község feladata, hogy gondoskodjon minden olyan lakosról aki erre rászorul, akinek nem megfelelô a szociális helyzete, nem megfelelô az egészségügyi állapota vagy elérte a nyugdíjkorhatárt.

\section{Felhasznált irodalom}

- DŽUKA, J. 2004. Psychologické dimenzie kvality života. Prešov: Prešovská univerzita v Prešove, 2004. 519 s. ISBN 80-8068-282-8.

- FRIEDLOVÁ, K. 2002. Bazální stimulace, pojetí konceptu. In Sborník Multioborové, interdisciplinární a medzinárodní kooperace v ošetrovatelství. Olomouc, 2002.

- FRIEDLOVÁ, K. 2006. Bazální stimulace pro učitele předmětu ošetřovatelství 1. a 2. díl. 1. vyd. Frýdek-Místek: Institut Bazální stimulace, 2006. 100 s. ISBN 80-239-6132-2.

- FUX, M. 1991. Formazione alla Danzterapia. Milano: ODÓZ edizioni SRL, 1991. $79 \mathrm{~s}$.

- HORŇÁKOVÁ, M. 1999. Liečebná pedagogika. Bratislava: Perfekt, 1999. 187 s. ISBN 80-8046-126-0.

- KRONIKA DOMOVA SOCIÁLNYCH SLUŽIEB MAŇA

- MATUlay, K. et al. 1986. Mentálna retardácia. 1.vyd. Martin: Osveta, 1986. 336 s. ISBN 70-077-86. 
- MIESTNA KRONIKA OBCE MAŇA

- MOJŽÍŠOVÁ, A. - LACINOVÁ, J. - ŠMBEROVÁ, J. 2000. Model canisterapie. In Kontakt. ISSN 1212-4117, 2000, roč. II, č. 4, s. 215-219.

- ONDREJKA, I. - DRÍMALOVÁ, M. - FRANK, V. 2000. Kvalita života pri depresívnych stavoch. In Psychiatria. ISSN: 1335-423X, 2000, roč. VII, č. 2, s. $76-81$.

- ŠVARCOVÁ, I. 2003. Mentální retardace: vzdelávání, výchova, sociální péče. 2. vyd. Praha: Portál, 2003. 192 s. ISBN 80-7178-821-X. Zákon č. 448/ 2008 Z.z. o sociálnych službách a o zmene a doplnení zákona č. 455/1991 Zb. O živnostenskom podnikaní (živnostenský zákon) v znení neskorších predpisov

- ZELEIOVÁ, J. 2002. Muzikoterapia - dialóg s chvením. Východiská, koncepty, princípy a praktická aplikácia. Bratislava : ÚHV SAV, 2002. 310 s. ISBN 80-968279-6-0. 
